\title{
An Assessment Of Time Variation In Solid And Hollow Floor Construction In Lagos State
}

\author{
Olumide Afolarin Adenuga \\ Department of Building, \\ Faculty of Environmental Sciences \\ University of Lagos, Lagos Nigeria \\ oaadenuga@yahoo.com
}

\author{
Gboyega Sotunbo \\ Department of Building, \\ Faculty of Environmental Sciences \\ University of Lagos, Lagos Nigeria
}

oaadenuga@yahoo.com
DOI 10.5592/otmcj.2014.1.8

Research paper

\section{Keywords}

Reinforced Concrete, Solid Slabs, Hollow Slab, Time Variation and Project Delivery
THE CHOICE OF CONSTRUCTION METHOD EMPLOYED FOR CONSTRUCTING SUSPENDED SLABS IN BUILDINGS TEND TO IMPACT SIGNIFICANTLY ON THE DELIVERY TIME OF BUILDING PROJECT. Thus, this study aims at assessing the impact of various construction methods on duration for constructing hollow and solid floor slabs in buildings in Lagos State, Nigeria. The research design for this study was a survey design approach and the populations of the study were professionals involved in construction projects; Architects, Civil Engineers, Builders, Quantity Surveyors, Building Services Consultant and Contractors. These are the major participants in the construction industry in Lagos State, Nigeria. The analysis is based on 46 (forty-six) returned questionnaires out of the 60 (Sixty) questionnaires administered. The data from the questionnaires were analyzed using descriptive statistics tools such as frequency, percentage mean ranking while the hypothesis were tested with a paired sample t-test tool. It was found that the systems or methods of slab construction well known to the respondents are cast in situ, precast and semi-precast. The Cast in-situ beam and slab construction ranked as the most frequently adopted method followed by flat slab, hollow clay pot and waffle slab construction. In terms of construction time, placing reinforcement and construction of formwork takes more time than other processes in solid slab construction while in construction of reinforced cast in situ concrete hollow slab; formwork construction, placing hollow bricks or blocks or moulds on formwork and curing concrete takes more time than the other processes involved. The study's major recommendation is that, adequate and careful analysis should be conducted before taking a decision on the choice of floor system been adopted for any project. 


\section{Background to the study}

Building designs and constructions could be dated back to the existence of man on earth, and over the years, various designs and construction methods have evolved. These evolutions have led to the newest or modern designs and construction methods of various components or elements of a building; such as floors, wall, ceilings and roofs. For instance, the design and construction of floor slabs are usually solid, adequately reinforced in 2-direction and concreted. The construction of these slabs usually requires much formwork, high number of reinforcement provided in both ways (top and bottom) and high volume of concrete which resulted in an ample time or duration of construction. But over the recent decades, engineering researches have brought forth new designs that have led to new construction methods of floor slabs. These modern designs now give birth to entirely new construction methods that totally differ from the traditional way of constructing a solid slab. Hollow floor slabs, a product of modern designs, now require less reinforcement, less formwork and less concrete as a result of the holes, space, foams and balls that are incorporated in the slab. These now require a different method of on-site construction of such slabs to achieve its design which could enhance time savings during construction. Lai (2010) attested to the fact that holes or voids, which are created in the floors replaces the ineffective concrete in the neutral zone of the slab, thereby decreasing the dead weight and increasing the efficiency of the slab. Thus, voids or holes are formed within the slab system. These also give a significant advantage over the conventional solid slabs in terms of reduced material usage (reinforcement and concrete), reduced cost, enhance structural efficiency, decrease construction time and it is a new technology in the construction industry. In either way, floor slabs could be fabricated off-site (as pre-fabricated or pre-cast) and just brought to site for assemblage. The eventual on-site assemblage of these slabs will require newer technology and methods different from the entire on-site cast in-situ construction with construction time variation. Lutz (2002) investigated hollow floors from the aspect of prefabrication. In this method, the floor is manufactured or prefabricated from the factory and just brought to site for assemblage through anchorage. One of the advantages of this method is the delivery in time which cannot be compared to the in-situ construction. Hence, the variations in the duration of construction of these structures cannot be under rated. The variance in these two types of floor system could be linked to their method of construction or installation. Therefore, the objectives of the study are to identify the construction methods of hollow and solid floor slabs in construction projects in Lagos State and determine the variation in the time of production of the two floor systems.

\section{Types Of Concrete Floor Systems}

\section{Cast In-situ Floor Systems}

This class of concrete floor system entails physically constructing the floor slab by mixing, casting in between formwork and hardening of concrete on site. Cast in-situ reinforced concrete structures consist of horizontal elements (beams and floors) and vertical elements (columns and walls) connected by rigid joints. Cast in-situ floor system could be subdivided into monolithic (solid) reinforced in-situ floor slabs and monolithic hollow (ribbed) floor slabs.

\section{Pre-cast Floor System}

Pre-casting offers the advantages of off-site manufactured under factory conditions and fast erection on site. When combined with pre-stressing, additional benefits of long span and high load-capacity can be obtained. The precast floor elements are usually simply supported before a topping concrete is placed to complete the system. Pre-cast floor systems are produced to specification and are all in modulus (CCAA, 2010). Pre cast floor system could be subdivided into pre cast solid reinforced slabs and hollow core (Pre cast or Pre stressed).

\section{Construction Methods Of Cast In-Situ Floor System}

Generally, the on-site construction method of any cast in-situ floor slabs could be summarized as follows: Construction of formwork, placing of reinforcements, Pouring of concrete or casting and removal of formwork (Rupasinghe \& Nolan, 2007); under these four steps, the construction process of monolithic solid slab and hollow clay pot slab will be examined.

\section{Monolithic Solid Slab Construction}

Monolithic reinforced solid slabs are slabs which are constructed on-site as a unit with fresh concrete. Below is the construction process of a monolithic reinforced slab.

\section{Formwork construction}

Formwork was described as a structure, usually temporary, used to contain poured concrete to mould it to the required dimensions and support until it is able to support itself. It consists primarily of the face contact material (platform) and the bearers that directly support the face (prop) contact material (Rupasinghe \& Nolan, 2007). Lightweight horizontal panel formwork systems used for slab construction generally consist of a series of interconnected falsework bays, independent props or system scaffolds and supporting pre-formed decking panels. These can include primary beams spanning between props and supporting a number of panels. 
Placing of reinforcement

CCAA (2010) opined that the placement of reinforcement at strategic locations ensures great flexibility during the design and construction stages in insitu concrete construction. Bimel and Tipping (1997) stated that deformed bars, bar mats, or welded wire reinforcement usually are required in suspended structural floors as part of the structural design. Reinforcements are used to strengthen concrete for tension forces in structures as concrete is weak in tension but strong in compression (Rwamamara, Simonsson, \& Ojanen, 2010). Reinforcements are often delivered to sites in tonnes of standard length in Nigeria and are later cut into pieces of required length. The pieces are then laid or placed on the form work, in required or calculated spaces and then fixed together by an experienced iron fixer (bender) with a binding wire, in its final location or position. Rwamamara et al (2010) agreed with CCAA (2010) that the placement of reinforcement on the formwork on-site gives a great advantage of flexibility on site during placement. Generally, (BS 8110, 1997) the sizes of reinforcement used on sites varies from $12 \mathrm{~mm}-25 \mathrm{~mm}$ diameter, depending on the maximum moment to resist, and the spaces between each bars varies from 150mm - 250mm.

After placement of reinforcement, concrete spacers are used to maintain a good space between the formwork and the bars to give a cover of at least $20 \mathrm{~mm}$. this is done to prevent the bars against moisture attack and enhance fire resistance. In solid slab construction, reinforcements are provided in both directions as shown above, except for one way solid slab that has its reinforcement in just one direction. The provision of reinforcement in two ways in a solid slab is the aspect that affects delivery time.

\section{Pouring or casting of concrete}

Floor concrete requirement differ from those of other concrete used in the structure. Concrete is made up of cement, aggregate (sand, granite-19-25 mm) and potable water. In addition to meeting structural requirements, concrete for floors should provide adequate workability, durability and strength necessary to obtain the required finish and floor surface profile (Bimel et al, 1997). Concrete for floors, usually of mix 1:2:4$19 \mathrm{~mm}$ is used on site. This batch is either mixed by hand or by machine (mixer). A thorough mix is required to attain a required consistency and workability. In a situation where labours are used in placing the concrete, the labours placed the mixed concrete through head pans carefully over the fixed reinforcements and then vibrated to prevent any event void. The concrete is tapped to compact and give an even surface. The placed concrete is allowed to set for at least 28 days with constant curing to attain its workable strength.

In a situation where truck mixer is used to mix and pneumatic concrete pump or crane with bucket is used to discharge in position, the concrete is pumped from the mixed truck through the pneumatic pump or carried through a bucket attached to a crane, up to the point of discharge and then discharged. Skilled masons immediately spread the concrete into position, tapped, compacted and finished to requirement. The floor is then left for $\mathbf{2 8}$ days to attain its self-supportive strength before the formwork is removed. The thickness of the slab according to BS8110 (1997) is between 150 - 30omm depending on the design.

\section{Removal of the formwork}

After the concrete floor has attained its 28 days strength or more, the formwork can then be struck off carefully by skilled carpenters. BS8110 (1997) suggested that formwork should be removed without shock, as the sudden removal of wedges is equivalent to an impact load on the partially hardened concrete. The code suggested also that formwork should not be removed or struck off the suffix of the slab earlier than 28 days.

\section{Construction of Monolithic Hollow}

Clay Pot Slabl

Hollow (Ribbed) floors are floors economically designed and constructed using hollow blocks, removable foams or permanent voids former such as clay pots. This type of floors have reduced self weight compared to the solid slabs. This is due to the fact that some of the concrete in the neutral zone are removed. Ribbed slab are very adaptable for accommodating a range of service openings. The methods of hollow clay pot construction are as follows; Construction or Laying of formwork, Placing of pots, Placing of reinforcements, Pouring of concrete or casting and Removal of formwork.

\section{Construction of formwork}

Formwork as described by Rupasinghe and Nolan (2007) as a structure, usually temporary, used to contain poured concrete to mould it to the required dimensions and support until it is able to support itself. It consists primarily of the face contact material (platform) and the bearers that directly support the face (prop) contact material. Lightweight horizontal panel formwork systems used for slab construction generally consist of a series of interconnected false work bays, independent props or system scaffolds and supporting pre-formed decking panels. These can include primary beams spanning between props and supporting a number of panels. This is similar to the solid concrete slab formwork.

The constructions of the formwork for hollow clay pot slabs are usually done in two ways. These are;

1. Constructing or laying the formwork to cover the whole area of the floor slab and then the pots laid on them.

2. Constructing or laying the formwork just directly under the ribs of the pot. This form is actually the type that affects the time for formwork. 


\section{Placing of the clay pots}

After the formwork is set, next is the placing of the hollow clay pots. There are various types of pots available for used, depending on the structural design. The product varies from standard classic pots of size $400 \times 200$ $x 250 \mathrm{~mm}$ and so on. The pots, when delivered to site must be stacked properly before use. In the event of laying the pots, they must be carefully laid, head to head along the shorter direction as shown in the pictures below. The edged pots must be sealed with cement and sand mortar to prevent the concrete filling the hole. Pots laid parallel to one another forms the rib in between them to receive reinforcement and concrete. The rib formed could be between 100mm - 150mm wide, thickness of topping between $50 \mathrm{~mm}$ - 170mm (BS8110, 1997). In any case where it will require that the pot be cut into two at the side of the beam or where it will go into the beam, the pot is completely removed and the portion of the slab is designed and cast as solid slab. In placing the pots, breakages must be avoided because breakages of these pots will reduces the structural characteristics of the entire slab after casting. Usually, after laying the pots service pipe are laid and fixed in position through the pots or ribs.

\section{Placing of reinforcements}

Bimel, et al (1997) stated that deformed bars, bar mats, or welded wire reinforcement usually are required in suspended structural floors as part of the structural design. Reinforcements are used to strengthen concrete for tension forces in structures as concrete is weak in tension but strong in compression (Rwamamara et al, 2010). Reinforcements are often delivered to sites in tonnes of standard length in Nigeria and are later cut into pieces of required length. The ribs usually require two pieces of reinforcement (bottom) and may be one at the top to complete a triangular stirrups section.
In design, the top reinforcements are usually eliminated and the stirrups shaped in U-form to be hanged on the pots. This is due to the fact that the top bars serve no purpose so it is eliminated. Unlike the solid slabs which are reinforced in both directions, ribbed slabs of hollow clay pot are reinforced just in one direction of the rib. This, apart from the less form work, reduces construction period due to the reduction in reinforcement. Generally, (BS $8110,1997)$ the size of reinforcement used on sites varies from $10 \mathrm{~mm}-16 \mathrm{~mm}$ diameter, depending on the maximum moment to resist.

After placement of reinforcement, concrete spacers are used to maintain a good space between the formwork and the bars in the ribs to give a cover of at least $20 \mathrm{~mm}$. This is done to prevent the bars against moisture attack and enhance fire resistance. In topping, no serious reinforcement is required according to BS8110 (1997), but wire mesh is usually provided to prevent cracks. Considering the cost of a standard wire mesh, $6 \mathrm{~mm}$ mild steel bar are provided over the pots as mesh to resist cracks in the thin $50-75 \mathrm{~mm}$ topping. If $6 \mathrm{~mm}$ diameter bars are used, the centre to centre space must not be greater than $300 \mathrm{~mm}$ (usually, 150$200 \mathrm{~mm}$ spacing are used on site). This is to ensure that it lies within the top of the pots and not protrude through the spacing.

\section{Casting of Concrete}

Before casting, the deck must be kept clean of any materials on the pots and ribs, and the surface must be wet to prevent sudden drying of the topping which could lead to cracking. Concrete for this type of floors are usually of mix $1: 2: 4-19 \mathrm{~mm}$. This batch is machine mixed. A thorough mix is required to attain a required consistency and workability. In a situation where labours are used in placing the concrete, the labours placed the mixed concrete through head pans carefully in the ribs and over the pots. The rib must be vibrated to prevent any event void in it. The concrete is tapped to compact and give an even surface.

In another situation where truck mixer is used to mix and pneumatic concrete pump or crane with bucket is used to discharge in position. The concrete is pumped from the mixed truck through the pneumatic pump or carried through a bucket attached to a crane, up to the point of discharge and then discharged. Skilled masons immediately spread the concrete into position, vibrated, tapped, compacted and finished to requirement. The supervisor must ensure that the mesh is well embedded in the concrete to avoid exposure. During casting, continual check must be carried out on the propping to ensure that nothing has moved or sagged, as problems can only be rectified within half an hour of placing the concrete over the affected area. This is to ensure adequate prevention against deflection during casting. The floor is then left and cured for 28 days to attain its self-supportive strength before the formwork is removed. The total depth of the slab according to BS8110 (1997) depends on the design which is a factor of the height of pot used and of topping.

\section{Removal of formwork}

After the concrete floor has attained its 28 days strength or more, the formwork can then be struck off carefully by skilled carpenters. BS8110 (1997) suggested that formwork should be removed without shock, as the sudden removal of wedges is equivalent to an impact load on the partially hardened concrete. The code suggested also that formwork should not be removed or struck off the suffix of the slab earlier than 28 days.

Pre-cast or Prefabricated Floor Slabs Traditional cast-in-situ concrete floor systems involve the use of temporary shuttering which adds to the cost of 
construction and time. Use of standardized and optimized precast floor components where shuttering is avoided prove to be economical, fast and better in quality. Some of the prefabricated flooring components available but not limited to, are: precast Reinforced Concrete slabs/ planks and precast hollow concrete panels.

\section{Pre-cast Hollow Concrete Slab}

Hollow core floor planks (slabs) are precast, prestressed units produced on long-line casting beds using slide forming or extrusion methods. During manufacturing, cores are formed throughout the length of the unit, reducing its self-weight. Planks or slabs are usually $1200-\mathrm{mm}$-wide, though it could be produce $2400-\mathrm{mm}$-wide units. These wider units may require increased crane capacity but offer greater speed of placement, less joints, grouting and sealing. Thicknesses of slabs vary from 150-400 mm in 50-mm increments. The thickness is determined by span, loading, fire rating and cover to reinforcement to satisfy exposure conditions. The economical typical span for a precast hollow core unit is approximately $D \times 30$ to $D \times 35$ where $D$ is the depth of the precast unit plus topping. Where slenderness ratios fall between 35:1 and 45:1, panels should be checked for vibration-resonance effects. Spans exceeding 45:1 should not be used. Planks may be used as plain sections or topped to give a composite unit. The topping increases plank capacity and fire rating. It provides a level surface or drainage falls and is recommended for most building work. For economy, the structure should be dimensioned to accommodate the $1200-$ or $2400-\mathrm{mm}$ modular plank width (CCAA, 2003).

Lai (2010) attested to the fact that holes or voids which are created in the floors replace the ineffective concrete in the neutral zone of the slab, thereby decreasing the dead weight and increasing the efficiency of the slab. For instance, in the clay pot slab construction, the neutral zone of the concrete is replaced with the hollow clay pots while in the case of hollow slabs, the concrete in the neutral zone are removed without replacing it with any other materials. Thus, voids or holes are formed within the slab system. These also give a significant advantage over the conventional solid slabs in terms of reduced material usage (reinforcement and concrete), reduced cost, enhance structural efficiency, decrease construction time and it is a new technology in the construction industry. Lutz (2002) investigated hollow floors from the aspect of prefabrication. In this method, the floor is manufactured or prefabricated from the factory and just brought to site for assemblage through anchorage. The advantage of this method in material saving, good quality control, and delivery in time and within cost, can not be compared to the in-situ construction.

Hollow floors, which could also be called hollow core slabs can be used for most applications requiring a floor system in Office buildings, auditoriums, hotels, commercial buildings, residential dwellings, houses of worship, nursing homes and educational facilities, are all ideal applications. This is because of the advantage it gives in large span and of course its aesthetics cannot be compared to that of the solid slabs. In either way, floor slabs could be fabricated off- site (as pre-fabricated or pre-cast) and just brought to site for assemblage. The eventual on-site assemblage of these slabs will require newer technology and methods different from the entire on-site construction. Floors, which is a component part of a building was major course of the study.

\section{Construction Period}

\section{Comparison Between Hollow} Slabs And Solid Slabs System

Kadir, (2006) discovered that significant difference occur between in-situ slab construction and precast system up to about 76 per cent, with respect to delivery time. From these results, it could be concluded that the difference in actual labour productivity between conventional and precast system mainly contributed by the cycle time (difference of 76 per cent) rather than the crew size (difference of 18 per cent). Shorter cycle time implies that total project construction time would also be reduced, hence minimizing management overhead and meaning that owners can occupy their house earlier. Visser, (2009) discovered that waffle moulds or precast brick result into additional time of construction for in situ hollow slabs due to the placement of forms on slab formwork, erection time amounts to the time it takes to construct a flat slab, with the additional time of moulds placement. Fixing of reinforcement between forms can also prove to be a more time consuming task. The fixing of steel reinforcement in between and on top of the moulds or bricks is also more strenuous than on a flat surface and proves to be more labour intensive. Thus, the construction period for in-situ hollow slabs may be higher than that of solid slabs due to the placement of moulds or bricks to form the hole on site. Basri, (2008) Captured in the study of construction period as one of the critical factor in the choice of a slab system that, $83 \%$ of the respondents agreed that precast construction would result to faster completion of projects. In this survey, $100 \%$ of the projects were either completed in the same period of time as conventional construction; or even faster. $26 \%$ of the projects cut the $83 \%$ construction time while $52 \%$ recorded an astonishing savings in time. Of cause, it is logical to note that the off-site production of the floor system has reduced greatly the on-site time required for construction. Because onsite activities are only left with hoisting, placing and finishes which takes less time and less work force. It then clearly showed that the reduction in construction time is the most obvious benefit of precast system of slab constructions. 


\section{Research Method}

The study was carried out in Lagos State, Nigeria. Lagos State is situated in the South Western part of Nigeria. Lagos state was chosen as a result of the large number of construction works going on in the state. The populations for this study are Architects, Civil Engineers, Builders, Quantity Surveyors, Consultant and Contractors who are major participant in the construction activities in the construction industry in Lagos State. The research design for this study is a survey design approach (quantitative) through which data were collected. Survey design approach was adopted because this will give varying opinions on the subject by different professional respondents which would be of great influence on the analysis. The primary data were collected through the administration of structured questionnaire and site visitation while the secondary data were gathered from the review of past projects, journals, conference proceedings articles and the internet.

A total number of 60 (sixty) questionnaires were distributed which represent $100 \%$ for the study. In all, a total of 46 questionnaires were returned which represent $76.7 \%$ and 14 questionnaires were not returned which represent $23.3 \%$ of the total $100 \%$. Since the 46 returned questionnaires represent over $75 \%$ (i.e $76.7 \%$ ) of the total distributed, the sample size for the research was set at 46 (forty-six) based on the returned questionnaire. The sample frame for the study therefore contain 27 (twenty-seven) Civil Engineers, 14 (fourteen) Quantity Surveyors and 4 (four) Builders to make a total of 46 respondents. The sampling technique for this study was non-probabilistic, specifically convenience sampling technique. This was adapted to source for the required information for the study within Lagos State. This technique was used because of its ease in getting in contact with those who are qualified and experienced to provide information based on the objectives and the direction of the study (transverse). Descriptive and inferential tools were used to analyze the data for the study. Descriptive statistical tools such as frequency, percentage, mean, ranking and paired sample t-test tool (inferential tool) were used in the analysis.

\section{Data analysis and findings}

Table 1 above described the responses of the respondents on the various methods of floor construction known to the respondents. It was observed from the study that cast in-situ method of slab construction is well known to almost all the respondents with a mean value of 3.93 and ranked 1st, while precast and semi-precast followed with mean value of 3.43 and 2.63 and are ranked 2 nd and 3 rd respectively among the known methods of slab construction in Nigeria construction industry. This could be as a result of the technological development of the Nigeria construction industry. Contractors are more knowledgeable on

\begin{tabular}{|c|c|c|c|c|}
\hline Construction method & & & $\begin{array}{l}\text { Mean } \\
\text { Value }\end{array}$ & Rank \\
\hline Cast in-situ & & 3.93 & 1 \\
\hline Precast/ prefabricated & & 3.43 & 2 \\
\hline Semi precast & & 2.63 & 3 \\
\hline
\end{tabular}

Note: Well Known = 4, Known = 3, Fairly Known = 2, Not Known = 1, No Response = o, Percentage $=\%$ and Total Number of Respondents $=\mathrm{N}$

\section{Table 1. Construction methods used for solid and hollow floors}

cast in-situ because it is more of labour based and less of plant based, but other methods like pre cast are more of technology and plant based that cast in situ.

\section{Level of usage of floor systems}

The analysis of the level of usage of different types of floor system are shown in Table 2 above. Cast in situ and pre cast were considered. Of the cast in situ, it was observed that beam and slab construction is used very often by all the respondents as it pulled a mean value of 3.96 and ranked 1st among other system. Flat slab followed closely with a mean value of 3.65 and ranked 2 nd. Hollow clay pot slab construction was fairly used as it ranked 3 rd with a mean value of 3.24 while waffle, another type of floor was only said to be least used as it ranked 5 th with a mean value of 2.39 . This shows vividly that most respondents used very often in construction, cast in situ beam and slab, flat slab and hollow slab while hollow block and waffle are rarely used in construction.

of the pre-cast, the table above shows that precast beam and slab construction is used very often in construction as it is ranked 1st with a mean value of 3.37 among the precast group. Precast flat slab which ranked 2 nd with a mean value of 3.17 has a low usage level compared to precast beam and slab while pre-cast hollow clay pot slab and precast waffle slab construction are not frequently used or are not even used at all in the construction industry. It thus shows obviously that most respondents only know about precast beam and slab, flat slab and hollow slab construction but knows next to nothing about precast waffle. The table also revealed a trend that cast in-situ method of slab construction has a high level of usage than precast method.

\section{Difference in construction period} The result of the level of time required in construction process of reinforced hollow concrete slab and reinforced solid concrete slab are tabulated in 


\begin{tabular}{|c|c|c|c|}
\hline $\begin{array}{c}\text { Types of slab construction } \\
\text { (Cast in situ) }\end{array}$ & & Mean Value & Rank \\
\hline Beam and Slab & & 3.96 & 1 \\
\hline Flat Slab & 3.65 & 2 \\
\hline Hollow Clay Pot & 3.24 & 3 \\
\hline Hollow Block & 2.80 & 4 \\
\hline Waffle Floor & & 2.39 & 5 \\
\hline (Precast) & & 3.37 & 1 \\
\hline Beam and Slab & & 3.17 & 2 \\
\hline Flat Slab & 2.39 & 3 \\
\hline Hollow Clay Pot & & 2.13 & 4 \\
\hline Hollow Block & & 2.11 & 5 \\
\hline Waffle Floor & & & \\
\hline
\end{tabular}

Note: Well Known $=4$, Known $=3$, Fairly Known $=2$, Not Known $=1$, No Response $=0$, Percentage $=\%$ and Total Number of Respondents $=\mathrm{N}$

\section{Table 2. Level of Usage of types of floor slab by the respondents}

Table 3 below. The table has four sections which are cast in situ solid slab, cast in situ hollow slab, precast solid slab and precast hollow slab. On the process of construction of reinforced cast in situ concrete solid slab, time required to place reinforcements, time required for formwork construction and the time required for the concrete to cure with mean value of 3.93 , 3.72 and 3.22 are the three highest mean values and ranked 1st, 2nd and 3 rd respectively. While the required time to place concrete and the time required to strike-off formwork with mean value of 3.15 and 2.78 are the two least mean values and are ranked $4^{\text {th }}$ and 5 th respectively. It thus, means that placing reinforcement and construction of formwork takes more time than other process in solid slab construction process or method. On the process of construction of reinforced cast in situ concrete hollow slab, time required for formwork construction, time required to place hollow bricks or blocks or moulds on formwork and time required to cure concrete with mean value of $3.70,3.46$ and 3.24 are the three highest mean values and ranked 1st, 2nd and 3rd respectively. While time required in lay reinforcement in ribs, required time to place concrete and the time required strike-off formwork with mean value of 3.15, 2.97 and 2.74 are the three least mean values and are ranked 4 th, 5 th and 6 th respectively. It then implies that formwork construction, placing hollow bricks or mould on formwork and curing takes more time than other process in hollow slab construction process or method.

Precast concrete slab have a different construction method or process from what is obtained in cast in situ. Here, the units are manufacturer off site and brought to site for erection. Table 3 below also shows various time required for various process of precast slab construction. On precast solid slab, time required for off-site fabrication of units and transportation of units to site with mean value of 3.52 and 3.33 are the two highest mean and are ranked 1st and 2 nd respectively while the time required in erecting and placing units in position, and time required in grouting and casting toppings with mean value of 3.28 and 3.09 are least as they are ranked 3 rd and 4 th respectively. On precast hollow core/hollow slab, time required for off-site fabrication of units and transportation of units to site with mean value of 3.48 and 3.26 are the two highest mean and are ranked 1st and 2 nd respectively while the time required in erecting and placing units in position, and time required in grouting and casting toppings with mean value of 2.98 and 2.76 are least as they are ranked 3 rd and 4 th respectively.

\section{Duration of construction process of slabs}

Table 4 shows the result of response of the respondents on duration of cast in situ hollow slab to solid slab and cast in situ to precast slabs. Majority of the respondent affirms that duration or time of construction of cast in situ hollow slab is higher than that of solid slab (36 respondents) while just only 10 respondents affirm that the construction duration is lower. In the same vein, majority of the respondents (35 respondents) affirms also that the duration of construction of cast in situ slabs system is higher than that of precast system, while 10 and 1 respondent did not obliged as they settled for low and very low respectively. These shows that cast in situ hollow slab takes more time than cast in situ solid slabs as cast in situ construction system takes more time to construct than precast slab.

\section{Testing of Hypothesis}

Null Hypothesis (Ho): There is no significant difference in the construction time between solid and hollow floor slabs construction in construction projects.

Alternative Hypothesis $\left(\mathrm{H}_{1}\right)$ : There is significant difference in the construction time between solid and hollow floor slabs construction in construction projects.

To test this hypothesis, a paired sample t-test analysis was used.

Table 5 above shows a paired sample t-test on difference in construction time between cast in situ solid and hollow slabs in construction projects. The value 


\begin{tabular}{|c|c|c|}
\hline Process of Reinforced Concrete Slab Construction & Mean Value & Rank \\
\hline $\begin{array}{l}\text { (Cast in-situ solid slab) } \\
\text { Time required for formwork construction }\end{array}$ & 3.93 & 1 \\
\hline Time required to place reinforcement & 3.72 & 2 \\
\hline Time required to place concrete & 3.22 & 3 \\
\hline Time required to cure & 3.15 & 4 \\
\hline Time required to strike off formwork & 2.78 & 5 \\
\hline \multicolumn{3}{|l|}{ (In-situ hollow slab) } \\
\hline Time required for formwork construction & 3.70 & 1 \\
\hline $\begin{array}{l}\text { Time required to place hollow bricks or mould on } \\
\text { formwork }\end{array}$ & 3.46 & 2 \\
\hline Time required to place reinforcement in ribs & $3 \cdot 42$ & 3 \\
\hline Time required to place concrete & 2.15 & 4 \\
\hline Time required to cure & $3 \cdot 94$ & 5 \\
\hline Time required to strike off formwork & 2.74 & 6 \\
\hline \multicolumn{3}{|l|}{ (Precast solid slab) } \\
\hline Time required for off-site fabrication. & $3 \cdot 52$ & 1 \\
\hline $\begin{array}{l}\text { Time required for transportation } \\
\text { of units to site. }\end{array}$ & $3 \cdot 33$ & 2 \\
\hline $\begin{array}{l}\text { Time required for erection and placement } \\
\text { of units on site. }\end{array}$ & 3.28 & 3 \\
\hline Time required for grouting and casting topping & 3.09 & 4 \\
\hline \multicolumn{3}{|l|}{ (Precast hollow slab) } \\
\hline Time required for off-site fabrication. & 3.48 & 1 \\
\hline Time required for transportation of units to site. & 3.26 & 2 \\
\hline $\begin{array}{l}\text { Time required for erection and placement } \\
\text { of units on site. }\end{array}$ & 2.98 & 3 \\
\hline Time required for grouting and casting topping & 2.76 & 4 \\
\hline
\end{tabular}

Table 3. Process of reinforced concrete slab construction

\section{Duration of construction}

Cast in situ hollow slabs to solid slab

Cast in situ floors to precast floors system
Mean Value

3.00

2.98
Note: Very High $=5$, Moderately High $=4$, High $=3$, Low $=2$, Very Low $=1$, No Response $=0$ and Number of Respondents $=\mathrm{N}$

of $t(d f=45)$ is $-4.263, P<0.05$ with a two tailed $P$ value, sig.(2-tailed) of .000, $t$ is significant at $5 \%$ level. Therefore the null hypothesis Ho; there is no significant difference in the construction time between cast in situ solid and cast in situ hollow floor slabs construction in construction projects is rejected and the alternative hypothesis $\mathrm{H}_{1}$ : there is significant difference in the construction time between solid and hollow slabs construction in construction projects is accepted. Thus, there is difference in the construction time of the method of construction of solid and hollow slabs.

The same test was also done on precast method and the result is tabulated in Table 6.

Std. . Deviation = Standard Deviation, Std Error $=$ Standard Error, Df = Degree of Freedom, Sig. = Significance and $\mathrm{N}=46$

Table 6 above shows a paired sample t-test on difference in construction time between precast solid and precast hollow slabs in construction projects. The value of $t(d f=45)$ is 1.594, $P<0.05$ with a two tailed $P$ value, sig.(2-tailed) of .118, $t$ is significant at $5 \%$ level. Since 0.118 is greater than 0.05 therefore the null hypothesis $\mathrm{Ho}$; there is no significant difference in the construction time between cast in situ solid and cast in situ hollow floor slabs construction in construction projects is accepted for precast system. This is expected because precast solid and hollow slabs are all manufactured in the factory and all brought to site for erection and placement. The same process of construction applies to all precast units unlike cast in situ.

\section{Discussion of Findings}

It was revealed that, the system or method of slab construction well known to the respondents is cast in situ with a mean value of 3.93, precast and semiprecast with mean value of 3.43 and 2.63 


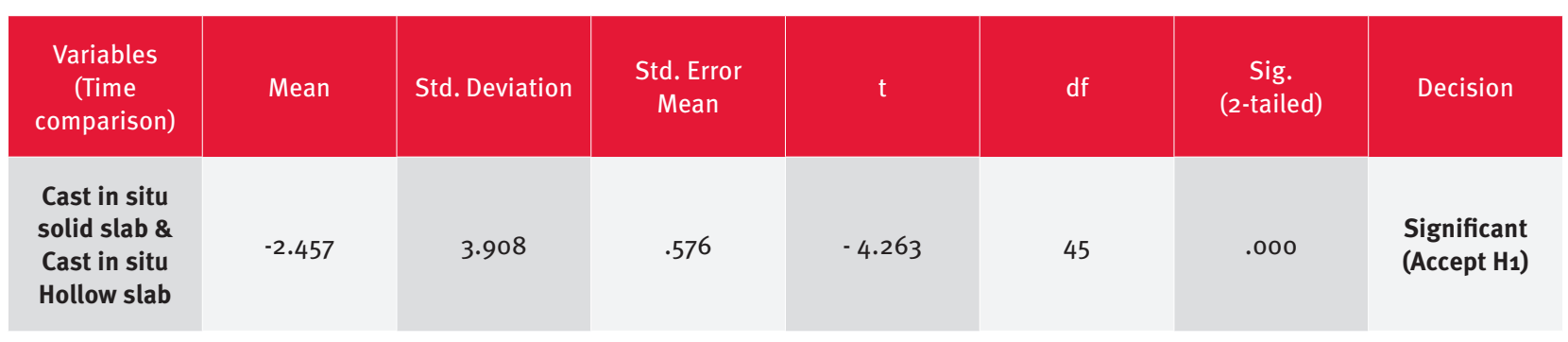

Std. Deviation $=$ Standard Deviation, Std Error $=$ Standard Error, Df $=$ Degree of Freedom, Sig. $=$ Significance and $\mathrm{N}=46$

Table 5. Paired sample t-test on Difference in construction time between cast in situ solid and cast in situ hollow slab

\begin{tabular}{|c|c|c|c|c|c|c|}
$\begin{array}{c}\text { Variables } \\
\text { (time } \\
\text { comparison) }\end{array}$ & Mean & $\begin{array}{c}\text { Std. } \\
\text { Deviation }\end{array}$ & $\begin{array}{c}\text { Std. Error } \\
\text { Mean }\end{array}$ & $\mathbf{t}$ & df & $\begin{array}{c}\text { Sig. } \\
\text { (2-tailed) }\end{array}$ \\
\hline $\begin{array}{c}\text { Precast } \\
\text { solid slab } \\
\text { \& Precast } \\
\text { Hollow slab }\end{array}$ & .739 & 3.144 & .464 & 1.594 & 45 & $\begin{array}{c}\text { Not } \\
\text { Decision }\end{array}$ \\
\hline
\end{tabular}

Std. Deviation $=$ Standard Deviation, Std Error $=$ Standard Error, $\mathrm{Df}=$ Degree of Freedom, Sig. $=$ Significance and $\mathrm{N}=46$

Table 6. Paired sample t-test on Difference in construction time between precast solid and precast hollow slab

and are ranked 2 nd and 3 rd respectively. This means that the respondents are familiar with cast in situ and pre cast/ prefabrication method while in the case of semi precast method, they are not familiar with the method. The findings correspond with Idrus and Newman, (2002) and Seeley, (1995) in terms of their classification of solid slab construction. They classified solid slab construction in majorly cast in situ and precast while semi precast was out of their classifications. Therefore, the major classification of slabs construction methods are cast in-situ and precast.

Beam and slab construction of slab was discovered to be well known to the respondents followed by flat slab and hollow clay pot slab while the respondents do not have a good knowledge of waffle slab construction under cast in situ method. Under precast method of construction, beam and slabs construction is well known in the construction industry followed by precast flat slab while the least known on the table is precast waffle slab construction. It then shows vividly that most respondents only know about precast beam and slab, flat slab and hollow slab construction but knows less to nothing about precast waffle.

In terms of the level of usage, the study revealed that cast in situ beam and slab construction is the most used, followed by flat slab while hollow block slab and waffle slab construction are less used. This implies that most respondents use very often in construction, cast in situ beam and slab, flat slab and hollow slab while hollow block and waffle are rarely used in construction. Of the pre-cast, precast beam and slab construction, precast flat slab construction, pre-cast hollow clay pot slab construction are mostly used while waffle construction is the least used. One can then say, that cast in situ construction method is most used in Nigeria construction industry while precast is still breeding or used mostly for special construction that requires it.

The result of the level of time required in construction process of reinforced hollow concrete slab and reinforced solid concrete slab revealed that time required to place reinforcements, time required for formwork construction and the time required for the concrete to cure are the three highest activities and are ranked 1st, 2 nd and 3 rd respectively. While the required time to place concrete and the time required strike-off formwork are the two least activities and are ranked 4th and 5 th respectively for cast in situ system of construction. Critically, this means that placing reinforcement and construction of formwork takes more time than other process in solid slab construction process or method. On the process of construction of reinforced cast in situ concrete hollow slab, time required for formwork construction, time required to place hollow bricks or blocks or moulds on formwork and time required to cure concrete are the three highest activities and ranked 1st, 2nd and 3 rd respectively. While time required in laying reinforcement in ribs, required time to place concrete and the 
time required to strike-off formwork are the three least and are ranked 4th, 5th and 6 th respectively. It then implies that formwork construction, placing hollow bricks or mould on formwork and curing takes more time than other process in hollow slab construction process or method. Precast concrete slab have a different construction method or process from what is obtained in cast in situ. Here, the units are manufacturer off site and brought to site for erection. Time required for off-site fabrication of units and transportation of units to site are the two highest and are ranked 1 st and 2 nd respectively while the time required in erecting and placing units in position, and time required in grouting and casting toppings are least as they are ranked 3 rd and 4 th respectively for precast solid slab. On precast hollow core/hollow slab, time required for off-site fabrication of units and transportation of units to site are the two highest and are ranked 1 st and 2 nd respectively while the time required in erecting and placing units in position, and time required in grouting and casting toppings are least as they are ranked 3 rd and 4 th respectively. The study therefore affirms that the duration or time of construction of cast in situ hollow slab is higher than that of solid slab. In the same vain, the duration of construction of cast in situ slabs system is higher than that of precast system. These shows that cast in situ hollow slab takes more time than cast in situ solid slabs as cast in situ construction system takes more time to construct than precast slab. This findings supports, Yin et al, (2007) and Basri, (2008) that, a significant time difference exists between the construction of solid and hollow cast in situ slabs, and that there is also a significant time savings between precast and cast in situ.

\section{Conclusions}

At the design stage, the choice of slab and its construction time or period for any project should be critically examined and analyzed to determine its implication on the total duration of the project so as to avoid prolonged construction period or unanticipated delay in the project delivery time which could be unpleasant to clients' cash flow and anticipations

Under the cast in-situ system, beam and slab construction is mostly used among the identified list, followed by flat slab, hollow clay pot and waffle slab construction respectively. This is evident as most upper floor slabs of residential and some office buildings in Nigeria are constructed of beam and slab while newer office buildings, commercial and other heavy engineering buildings are now constructed of hollow slabs, flat slabs and waffle slabs. While under pre-cast system, precast beam and slab construction, pre-cast hollow core or hollow slab and other forms of precast slabs are not often used, thus, one can then say that based on the result of the study, cast in situ construction method is most used in Nigeria construction industry while precast is still under-used or are most for special construction that requires it.

\section{References}

Bimel. C., (1997): Guide for concrete floor and slab construction. Reported by American Concrete Istitute (ACI) committee 302.1R. USA.

BS 8110, (1997): Structural Use of Concrete:

Part 1. Code of Practice for Design and Construction.Publication of British Standard Institution, London.

C and CAA, (2003): Guide to long-span concrete floors. Cement and Concrete Aggregates Australia 73b, Second Edition, (August), ISBN $1-877023-09-4$.

.Concrete Manufacturer Association, (2008): Hollow core slab system; Information Manual.First Edition.

Idrus, A. B and Newman, J. B, (2002): Construction related factors influencing the choice of concrete floor system. Journal of Construction Management and Economic., (2002), 20, 13 - 19. Taylor and Francis Ltd. $0144-6193$.

Kadir, M. R. Abdul, Lee, W.P., Jaafar, M.S., Sapuan, S. M. and Ali, A. A. A. (2006): Construction performance comparison between conventional and industrialised building systems in Malaysia. Structural Survey. 24 (5), 412-424.

Lai Tina. (2010): Structural behaviours of bubble deck slabs and their applications to light weight bridge deck. A Master's Thesis Submitted to the Department of Civil and Environmental Engineering, Massachusetts Institutes of Technology. Massachusetts, USA.

Lutz Clemens. (2002): Prestressed hollow core concrete slabs - Problems and possibilities in fastening techniques. Otto-Graf-Journal. (2002), 13.

Rupasinghe, R., and Nolan, E. (2007): Formwork for modern, efficient concrete construction. Publication of BRE. Garston, Watford. U.K.978-1-86081-975-9.

Rwamamara, R., Simonsson, P., and Ojanen, J. (2010): Advantages of industrialized methods used in small bridge construction.Poster session of the Proceedings at IGLC-18, (July), Technion, Haifa, Israel.

Seeley, H. Ivor. (1995): Building Technology (5th. Ed). Hampshire, UK: PALGRAVE.

Vanderwerf, A. Pieter, and Ridsdale, C. (1998): Concrete Floor Systems In Residential Construction; Proliferation of homes built with insulating concrete forms inspires wider use of concrete floors. The Aberdeen Group. Scotland.

Visser, W. D. (2009): Which type of slab is the most effective solution to concrete structures?. A Bachelor Degree Research Submitted the Department of Quantity Surveying, Faculty of Engineering, Built Environment and Information Technology. University of Pretoria. SA 